\title{
The Production, Separation and Stability of Pyoluteorin: A Biological Pesticide
}

\author{
Wei Wang, Hui Dong, Jingfang Zhang, Yuquan Xu and Xuehong Zhang \\ Key Laboratory of Microbial Metabolism, Ministry of Education, \\ School of Life Sciences and Biotechnology, Shanghai Jiao Tong University, \\ Shanghai 200240, \\ PR China
}

\section{Introduction}

Pyoluteorin (Plt, 4,5-dichloropyrrol-2-yl 2,6-dihydroxyphenyl), a polyketide antibiotic produced by certain strains of Pseudomonas spp., including the rhizobacteria Pseudomonas fluorescens CHA0 (Maurhofer et al., 1992), Pseudomonas fluorescens Pf-5 (Corbell \& Loper, 1995), Pseudomonas fluorescens S272 (Yuan et al., 1998) and Pseudomonas sp. M18 (Hu et al., 2005) et al., was first identified and separated by Takeda from Pseudomonas aeruginosa (Tekeda, 1958). Plt is a yellow crystal composed with a bichlorinated pyrrole linked to a resorcinol moiety (see Fig. 1), it can be completely dissolved in organic solvents such as methanol and chloroform (Wang et al., 2008). Plt can effectively inhibit phytopathogen fungi, including the plant pathogen Pythium ultimum, and suppress plant diseases caused by this fungus (Howell \& Stipanovic, 1980; Maurhofer et al., 1992; Maurhofer et al., 1994). Moreover, in some instances, it contributes to the ecological competence of the producing strain within Rhizosphere (Howell \& Stipanovic, 1980; Carmi et al., 1994; Yuan et al., 1998; Babalola, 2010).<smiles>O=C(c1cc(Cl)c(Cl)[nH]1)c1c(O)cccc1O</smiles>

Fig. 1. Chemical structure of Plt

Many studies have focused on the metabolic regulation of Plt biosynthesis to enhance Plt production in cell cultivation. It was reported that the transcriptional activator gene pltR linked to Plt biosynthetic genes is required for Plt production (Nowak-Thompson et al., 1999). Whereas the regulator gene pltZ, which is located downstream of the Plt gene cluster in the genome of Pseudomonas sp. M18, could repress Plt production (Huang et al., 2004). Plt biosynthesis could be enhanced by the amplification of the housekeeping sigma factor rpoD in Pseudomonas fluorescens CHA0 (Schnider et al., 1995). The two component regulatory system GacS/GacA could positively regulate Plt production (Laville et al., 1992; Whistler et 
al., 1998), and inactivation of rpoS (Sarniguet et al., 1995) or lon (Whistler et al., 2000) also resulted in the overproduction of Plt in Pseudomonas fluorescens Pf-5.

The culture conditions are usually important to the yield of any fermentation product. Carbon and nitrogen sources generally play a significant role because these nutrients are directly linked to cell proliferation and metabolite biosynthesis (Park et al., 2001; Casas Lopez et al., 2003; Li et al., 2008). In relation to this, Yuan et al. (Yuan et al., 1998) reported ethanol as a sole carbon source for Plt production by Pseudomonas fluorescens S272 cultivation in shake flasks. Duffy and Defago's study showed that Plt production was stimulated by glycerol but was repressed by glucose in cell culture of Pseudomonas fluorescens CHA0 (Duffy \& Defago, 1999). The influence of other environmental factors on Plt production was also investigated by many researchers. In Brodhagen's study, Plt was found to be induced by itself in cell culture of Pseudomonas fluorescens Pf-5 (Brodhagen et al., 2004). In Pseudomonas fluorescens S272 cultivation, high $\mathrm{NaCl}$ concentration or heat shock could increase the production of Plt (Nakata et al., 1999). Chloride could also increase Plt biosynthesis in cell culture of Pseudomonas fluorescens YGJ3 (Matano et al., 2010). The minerals, such as zinc, could enhance Plt production in cell cultivation of both Pseudomonas fluorescens CHA0 (Duffy \& Defago, 1999) and Pseudomonas fluorescens 4-92 (Saikia et al., 2009). However, there have been no reports on the effect of carbon and nitrogen ratio on Plt production through the fermentation of Pseudomonas spp. and no work was done on the scale-up fermentation for Plt production.

As a potential biological pesticide, understanding the stability of Plt under different environmental conditions as well as its residue in soil after incorporation into the environment was great important for its commercial use. Some analytical methods of Plt from the fermentation broth based on HPLC have been reported (de Souza \& Raaijmakers, 2003; La Fuente et al., 2004). Kim et al. described a method for quantification analysis of Plt in fermentation broth with liquid chromatography-mass spectrometric (LC-MS) (Kim et al., 2003). Wang et al. developed a succinct quantitative method of capillary zone electrophoresis (CZE) for the determination of Plt in fermentation liquor of Pseudomonas sp. M18 (Wang et al., 2005). Trace determination of Plt in soil was done by Dong et al. using capillary electrophoresis (CE) (Dong et al., 2011). The degradation of Plt in water under different $\mathrm{pH}$, temperature and light sources were studied by Zhang et al. (Zhang et al., 2010).

Pseudomonas sp. M18 is one of the plant growth promoting rhizobacteria (PGPR) selected in our lab, which can produce the secondary antifungal metabolites of Plt to suppress the root diseases caused by the soil-borne phytopathogens of crop plants (Hu et al., 2005). The chromosomally rsmA-inactivated and NTG mutation strain of Pseudomonas sp. M18R is a high Plt production strain obtained in our laboratory (Zhang et al., 2005). The identification of an effective medium formulation for Plt production is of great importance because it usually plays a pivotal role in cell growth and the production of metabolites. As a highly efficient anti-fungal metabolite, it is also important to develop the separation and purification method of Plt from its fermentation broth for large-scale preparation.

The medium optimization studies described in the literature have been conducted either by the "one-variable-at-a-time" technique or the "response surface method" (RSM) and "central composite design" (CCD) approach (Chang et al., 2002; Li et al., 2008). In this paper, the carbon or nitrogen sources and their initial concentrations were studied using the "one-variable-at-atime" method for Plt production from Pseudomonas sp.M18R. Central composite design and response surface analysis were then applied to determine the optimal carbon/nitrogen ratio for Plt production. Influence of mineral amendment on Plt production was also investigated, 
and the optimized medium was verified in both shake flask and bioreactor cultivation. The separation and purification method for Plt from the fermentation broth of M18R was investigated. The stability of Plt under different conditions were studied (Zhang et al., 2010), and a sensitive analytical method based on capillary electrophoresis (CE) for studying the degradation of trace amounts of Plt in soil samples was developed (Dong et al., 2011). The information obtained is considered fundamental and useful for the development of several Pseudomonas strain cultivation processes for efficient large-scale Plt production.

\section{Materials and methods}

\subsection{Bacterial strain and seed culture conditions}

The chromosomally rsmA-inactivated mutant strain of Pseudomonas sp.M18R was obtained as described by Zhang et al. (Zhang et al., 2005). The seed culture medium (with an initial $\mathrm{pH}$ of 7.2) consisted of the following components: glycerol, $18 \mathrm{~g} / \mathrm{L}$; peptone, $20 \mathrm{~g} / \mathrm{L}$; $\mathrm{K}_{2} \mathrm{HPO}_{4} \cdot 3 \mathrm{H}_{2} \mathrm{O}, 0.732 \mathrm{~g} / \mathrm{L}$; and $\mathrm{MgSO}_{4}, 0.514 \mathrm{~g} / \mathrm{L}$. The stock culture was maintained on agar slants, which were inoculated with M18R, incubated at $28^{\circ} \mathrm{C}$ for 12 hours, and then used for seed culture inoculation. For the seed culture, about $5 \mathrm{~mm}^{2}$ of the M18R bacterial slants was punched out with a sterilized cutter and was then transferred to a $250 \mathrm{~mL}$ Erlenmeyer flask containing $50 \mathrm{~mL}$ of the culture medium. The cultivation was maintained at $28^{\circ} \mathrm{C}$ on a rotary shaker $(220 \mathrm{rpm})$ for 10.5 hours, reaching an $\mathrm{OD}_{600}$ at about 1.1.

\subsection{Experiments on M18R fermentation}

The effects of carbon sources were studied using various carbon sources $(18 \mathrm{~g} / \mathrm{L})$ such as glycerol, sucrose, glucose, fructose, lactose, maltose, and ethanol. For the investigation of nitrogen sources, $20 \mathrm{~g} / \mathrm{L}$ of peptone, yeast extract, casein enzymatic hydrolysate, and casein acid hydrolysate were studied. For the investigation of initial carbon concentrations, different glycerol levels were used at 15, 18, 21, and $24 \mathrm{~g} / \mathrm{L}$. Furthermore, 12, 16, 20, and 24 $\mathrm{g} / \mathrm{L}$ peptone was used for the study of initial nitrogen concentrations. In the experiments on the effects of carbon/nitrogen ratios, glycerol and peptone levels in the medium were changed, and a statistical approach was used. For the studies of mineral sources, $0.02 \mathrm{~g} / \mathrm{L}$ ZnSO4, $\mathrm{CuSO}_{4}, \mathrm{CoCl}_{2}, \mathrm{FeSO}_{4}, \mathrm{MnCl}_{2}$ or $\mathrm{NaCl}$ was added individually into the control medium. The cells were harvested on $72 \mathrm{~h}$ to analyze Plt production.

Inoculation was done by transferring $7.5 \mathrm{~mL}$ of the above seed culture broth to a $150 \mathrm{~mL}$ fermentation medium in a $500 \mathrm{~mL}$ shake flask. The fermentation medium was the same as the seed culture medium except for the conditions studied. The cultivation was conducted at $28^{\circ} \mathrm{C}$ on a rotary shaker at $220 \mathrm{rpm}$. Multiple flasks were run under each condition for all cultures. The cultivation data represent the mean values with the standard deviations from three independent flasks.

The scale-up fermentation was carried out in a 10 L SY-3000E bioreactor (Shiyou Company, Shanghai, China) with $6 \mathrm{~L}$ optimized medium. The fermentation was conducted at an aeration rate of $1.6 \mathrm{vvm}$ and an agitation speed of $250 \mathrm{rpm}$ for $96 \mathrm{~h}$ and the shake flask culture was done as control.

\subsection{Central composite design}

RSM was used to optimize the glycerol and peptone ratios for enhanced Plt production based on CCD (Li et al., 2008). The second-order model used to fit the CCD experimental results is shown in Eq. (1): 


$$
y=\beta_{0}+\sum \beta_{i} x_{i}+\sum \beta_{i i} x_{i}^{2}+\sum \beta_{i j} x_{i} x_{j}
$$

where $y$ is the predicted response, $\beta_{0}$ is a constant, $\beta_{\mathrm{i}}$ is a coefficient for the linear effect, $\beta_{\mathrm{ii}}$ is a coefficient for the quadratic effect, $\beta_{\mathrm{ij}}$ is a coefficient for the interaction effect, and $x_{i}$ and $x_{j}$ are the coded levels of variables $x_{i}$ and $x_{j}$, respectively. The fitness of the second-order model was checked using the adjusted coefficient of determination $\mathrm{R}^{2}$, and its statistical significance was determined by the application of Fischer's $\mathrm{F}$ test. The software programs SAS (version 9.1 by SAS Institute Inc., NC, USA) and MatLab (version 7.1 by Mathworks, Inc.) were used for regression and graphical analyses of the data obtained, respectively.

\subsection{Measurement of cell growth and PIt production}

Cell growth was assayed in terms of optical density at $600 \mathrm{~nm}$ (OD600). A $1 \mathrm{~mL}$ culture broth was centrifuged at $12000 \mathrm{rpm}$ for $5 \mathrm{~min}$, and the sediments were re-suspended and diluted in distilled water.

The analytical procedures for Plt production were slightly modified as described by Zhang et al. (Zhang et al., 2005). For Plt extraction, $1 \mathrm{~mL}$ of each culture broth was mixed with the same volume of ethyl acetate. The upper layer was collected after complete agitation and centrifugation at $8000 \mathrm{~g}$ for $5 \mathrm{~min}$. The water layer was then extracted once more with 0.5 $\mathrm{mL}$ ethyl acetate. The combined extracts were finally dried in a desiccated vacuum at $40^{\circ} \mathrm{C}$ and then dissolved in $1 \mathrm{~mL}$ of HPLC grade methanol. Using a Shimadzu LC-8A HPLC apparatus equipped with a variable-wavelength UV detector (Shimadzu, SPD-8A), $20 \mu \mathrm{L}$ sample was analyzed by reverse-phase HPLC. A Zorbax SB-C18 column $(250 \times 4.6 \mathrm{~mm}$; $5 \mu \mathrm{m}$ ) was used at $25^{\circ} \mathrm{C}$. The mobile phase consisted of $70 \%$ methanol (vol) and $30 \%$ water (vol), with the flow rate kept constant at $1 \mathrm{~mL} / \mathrm{min}$. Plt was monitored and quantified at 308 $\mathrm{nm}$, and was then identified by comparison with its authentic sample.

\subsection{PIt purification}

Firstly, the fermentation broth was extracted with ethyl acetate and the crude Plt extract was obtained. Secondly, the crude Plt extract was separated by silica gel column chromatography with a glass column $\left(700 \times 50 \mathrm{~mm}^{2}\right)$ packed with $500 \mathrm{~g}$ analytical grade silica of 100-200 mesh. The column was eluted with benzene-acetic acid (20:1,vol) and the elution which contained Plt was collected and evaporated at $40^{\circ} \mathrm{C}$ to dry, and the residue was dissolved in methanol (HPLC grade) for further purification.

Preparative HPLC was conducted for further purification of Plt using a Tigerkin C-18 column $\left(300 \times 20 \mathrm{~mm}^{2} ; 10 \mu \mathrm{m}\right)$ under $25^{\circ} \mathrm{C}$ with $50 \%$ methanol as the mobile phase. The flow rate was kept constant at $15 \mathrm{~mL} / \mathrm{min}$ and the highest peak containing Plt was collected. Plt crystal was finally obtained after the elution was evaporated at $40^{\circ} \mathrm{C}$ to dry.

\subsection{Trace analysis of PIt in soil samples (Dong et al., 2011)}

A series of $\mathrm{Gly}-\mathrm{NaOH}$ buffers with different $\mathrm{pH}$ values and concentrations were prepared. The stock solution of internal standard (IS) was prepared by adding $1.0 \mathrm{mg}$ PCA into 10.0 $\mathrm{mL}$ methanol to fix its concentration at $100 \mu \mathrm{g} / \mathrm{mL}$. Standard solutions are prepared by dissolving Plt with different concentrations in methanol, forming a concentration gradient of $100,75,50,25,5,2,0.5 \mu \mathrm{g} / \mathrm{mL}$. All solutions and buffers were stored at $4^{\circ} \mathrm{C}$.

Plt was extracted from soil samples (air dried, mixed and sieved through a 2-mm sieve) with ethanol. The extraction procedure was performed as follows: the working standard solution 
was spiked into $10.0 \mathrm{~g}$ soil in an appropriate volume, which was ultrasonic extracted with 50 $\mathrm{mL}$ ethanol for $20 \mathrm{~min}$. The extraction liquid was collected and the solid sample was transferred to the Soxhlet extractor for $4 \mathrm{~h}$ using another batch of $100 \mathrm{~mL}$ ethanol. After mixing and evaporating all organic phases, the dry residue was dissolved in $5 \mathrm{~mL}$ methanol and then centrifuged at $3000 \mathrm{rpm}$ for $10 \mathrm{~min}$. A portion of the $500 \mu \mathrm{L}$ methanol layer was distributed to one Eppendorf tube with an addition of $125 \mu \mathrm{L} \mathrm{PCA}(25 \mu \mathrm{g} / \mathrm{mL})$. All solutions were stored at $4^{\circ} \mathrm{C}$ before injection into capillary.

The capillary-based experiments were carried out with an ACS 2000 HPCE apparatus (Beijing Cailu Scientific Inc., Beijing, China). The operating system is Windows XP professional SP2 with a HW-2000 chromatography work station (Qianpu Software Co. Ltd., Nanjing, China). Electrophoresis was performed in an untreated fused-silica capillary of $53 \mathrm{~cm}$ total length (44 cm effective length) $\times 75 \mu \mathrm{m}$ I.D. (375 $\mu \mathrm{m}$ O.D.) (Yongnian Optical Fiber Factory, Hebei, China). Before use, a new fused-silica capillary was pressure-rinsed with $0.1 \mathrm{M} \mathrm{NaOH}$ for 20 min, ultra-pure water for $20 \mathrm{~min}, 0.1 \mathrm{M} \mathrm{HCl}$ for $20 \mathrm{~min}$, ultra-pure water for $20 \mathrm{~min}$, and $\mathrm{CE}$ running buffer for $30 \mathrm{~min}$ orderly. The capillary was rinsed with $\mathrm{CE}$ running buffer for $5 \mathrm{~min}$ between injections and finally stored in water when not in use. The samples were injected in pressure mode at the inlet (13 mbar, for $45 \mathrm{~s}$ ). The ultimate working voltage was $10 \mathrm{kV}$.

Plt degradation study in soil was carried out with samples of both near-surface soil $(0 \sim 10 \mathrm{~cm}$ in depth) and rhizosphere soil (10 cm below surface), which were initially spiked with Plt at concentration of $500 \mu \mathrm{g} / \mathrm{kg}$. The extraction and analytical procedure were done as described above.

\subsection{Degradation of PIt under different conditions}

The degradation of Plt in water was done as describe by zhang et al. (Zhang et al., 2010). Plt solutions were prepared using our purified Plt and pure water, with the Plt concentrations varying between $121.5 \mathrm{mg} / \mathrm{L}$ and $626.5 \mathrm{mg} / \mathrm{L}$. Temperature was thermostat-controlled, and irradiation was carried out in a Pyrex vessel, using natural sunlight. Samples were taken from the reactor periodically and were analyzed immediately by HPLC. The sample treatment procedure was as follows: $200 \mu \mathrm{L}$ ethyl acetate was added to the reactive solutions to stop the reaction and extract Plt. The organic solution was then dehydrated to obtain a powder residue of Plt. All experiments were preformed in duplicate.

\section{Results and discussion}

\subsection{Optimization of M18R cultivation}

\subsubsection{Experiments on carbon sources and initial carbon concentrations}

Carbohydrates are important carbon and energy sources for bacterial growth and metabolite biosynthesis. In the cell culture of Pseudomonas fluorescens S272, a high Plt production titer was obtained using ethanol as sole carbon source (Yuan et al., 1998). In the current work, we investigated the effects of ethanol as well as various common carbon sources, such as glycerol, sucrose, glucose, fructose, lactose, and maltose on M18R cultivation. The time profiles of cell growth (OD600) and Plt production are shown in Fig. 2. It can be seen that the cell grew well in glycerol, glucose, and fructose, and the maximum cell density was obtained in glucose after 72 hours of cultivation. A higher Plt production titer was obtained in glycerol and fructose for M18R. The order of maximum Plt production titer was $540.2 \pm 20.0,401.2 \pm 24.8,270.1 \pm 20.1,212.6 \pm 12.6,119.7 \pm 11.7,37.2 \pm 3.2$, and $45.7 \pm 3.7 \mathrm{mg} / \mathrm{L}$ in glycerol, fructose, ethanol, glucose, sucrose, lactose, and maltose media, respectively. 

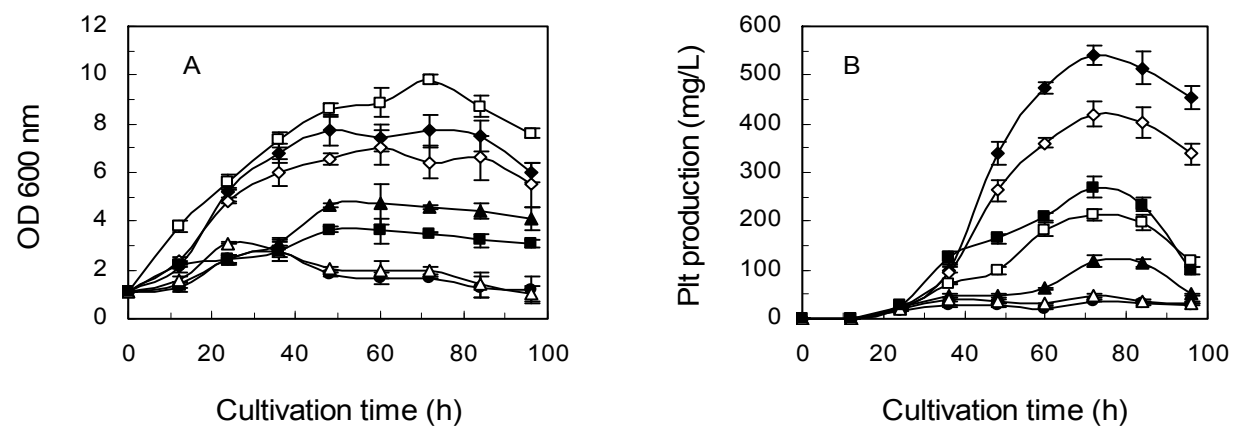

Fig. 2. Time profiles of cell growth (A) and Plt production (B) for the cell culture of $P$. M18R with different carbon sources $(18 \mathrm{~g} / \mathrm{L})$. Symbols for different carbons: glycerol (dark diamond), fructose (open diamond), sucrose (dark triangle), maltose (open triangle), ethanol (dark square), glucose (open square), and lactose (dark circle). The error bars in the figure indicate the standard deviations from three independent samples.

\begin{tabular}{|c|c|c|c|}
\hline $\begin{array}{c}\text { Initial glycerol concentration } \\
(\mathrm{g} / \mathrm{L})\end{array}$ & $\begin{array}{c}\text { Plt production } \\
(\mathrm{mg} / \mathrm{L})\end{array}$ & $\begin{array}{c}\text { Plt productivity } \\
(\mathrm{mg} / \mathrm{L} \text { per hour })\end{array}$ & $\begin{array}{c}\text { Plt yield on carbon } \\
(\mathrm{mg} / \mathrm{g})\end{array}$ \\
\hline $15(72 \mathrm{~h})^{\mathrm{a}}$ & $460.3 \pm 27.8$ & $6.39 \pm 0.39$ & $30.7 \pm 1.9$ \\
\hline $18(72 \mathrm{~h})$ & $568.3 \pm 30.1$ & $7.89 \pm 0.42$ & $31.6 \pm 1.7$ \\
\hline $21(60 \mathrm{~h})$ & $464.3 \pm 31.9$ & $7.74 \pm 0.53$ & $22.1 \pm 1.5$ \\
\hline $24(60 \mathrm{~h})$ & $423.7 \pm 19.8$ & $7.06 \pm 0.33$ & $17.7 \pm 0.8$ \\
\hline
\end{tabular}

Table 1. Effects of initial glycerol concentration on Plt production for P.M18R cultivation. a Cultivation time when the maximum Plt production was achieved.

Based on the above results, glycerol was selected as the carbon source for the cell culture of M18R. The effects of initial glycerol concentrations on Plt production are shown in Table 1. The highest production and productivity of Plt were obtained at an initial glycerol concentration of $18 \mathrm{~g} / \mathrm{L}$. The Plt production was decreased at high initial glycerol concentrations ( 21 or $24 \mathrm{~g} / \mathrm{L}$ ), the inhibitory effect of high initial carbon concentration on metabolite biosynthesis was also observed in ganoderic acid biosynthesis by Ganoderma lucidum (Fang \& Zhong, 2002).

\subsubsection{Experiments on nitrogen sources and initial nitrogen concentrations}

In the cell culture, both carbon and nitrogen sources are very important for cell growth and metabolite production. Various organic nitrogen, including peptone, yeast extract, casein enzymatic hydrolysate, and casein acid hydrolysate, were studied in this paper. The time profiles of cell growth (OD600) and Plt production for the cell culture of M18R in different nitrogen were shown in Fig. 3. It is evident that the cells grew well in peptone, and a maximum Plt production titre of $553.2 \pm 27.2 \mathrm{mg} / \mathrm{L}$ was achieved after 72 hours of cultivation in the peptone medium. The effects of initial peptone concentrations on Plt biosynthesis were further examined, the results of which are shown in Table 2 . The respective maximum Plt production and productivity of $568.3 \pm 30.1 \mathrm{mg} / \mathrm{L}$ and $7.89 \pm 0.42 \mathrm{mg} / \mathrm{L}$ per hour were obtained at an initial peptone concentration of $20 \mathrm{~g} / \mathrm{L}$. 

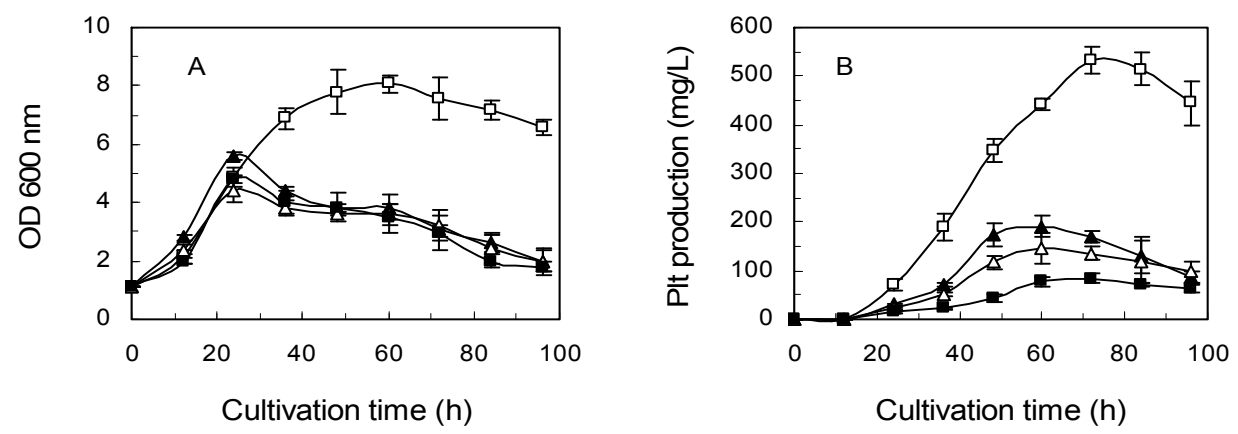

Fig. 3. Time profiles of cell growth (A) and Plt production (B) for the cell culture of $P$. M18R with different nitrogen sources $(20 \mathrm{~g} / \mathrm{L})$. Symbols for different nitrogens: peptone (open square), yeast extract (dark square), casein acid hydrolysate (open triangle), and casein enzymatic hydrolysate (dark triangle). The error bars in the figure indicate the standard deviations from three independent samples.

\begin{tabular}{|c|c|c|c|}
\hline $\begin{array}{c}\text { Initial peptone concentration } \\
(\mathrm{g} / \mathrm{L})\end{array}$ & $\begin{array}{c}\text { Plt production } \\
(\mathrm{mg} / \mathrm{L})\end{array}$ & $\begin{array}{c}\text { Plt productivity } \\
(\mathrm{mg} / \mathrm{L} \text { per hour })\end{array}$ & $\begin{array}{c}\text { Plt yield on carbon } \\
(\mathrm{mg} / \mathrm{g})\end{array}$ \\
\hline $12(84 \mathrm{~h})^{\mathrm{a}}$ & $393.2 \pm 30.8$ & $4.68 \pm 0.37$ & $21.8 \pm 1.7$ \\
\hline $16(72 \mathrm{~h})$ & $485.5 \pm 15.0$ & $6.74 \pm 0.21$ & $27.0 \pm 0.8$ \\
\hline $20(72 \mathrm{~h})$ & $568.3 \pm 30.1$ & $7.89 \pm 0.42$ & $31.6 \pm 1.7$ \\
\hline $24(60 \mathrm{~h})$ & $332.3 \pm 12.5$ & $5.54 \pm 0.21$ & $18.5 \pm 0.7$ \\
\hline
\end{tabular}

Table 2. Effects of initial peptone concentration on Plt production for the cultivation of P.M18R. a Cultivation time when the maximum Plt production was achieved.

\subsubsection{Experiments on carbon/nitrogen ratio}

The combined effect of carbon (glycerol) and nitrogen (peptone) was studied using the CCD because the concentrations of both carbon and nitrogen sources and their ratio are very important for metabolite production (Chang et al., 2002; Li et al., 2008). The levels of variables for CCD experiments were selected according to the results of the one-at-a-time strategy, and the coded $(-1.414,-1,0,1$, and 1.414) and real values of the variables at various levels are listed in Table 3. The experimental responses, along with the predicted response obtained from the regression equation, are also shown in Table 3.

Regression analysis was performed to fit the response function (Plt production) with the experimental data. From the variables obtained (Table 4), the model was expressed by Eq. (2), which represented Plt production (y) as a function of glycerol $\left(x_{1}\right)$ and peptone $\left(x_{2}\right)$ concentrations. Furthermore, the results of the F-test analysis of variance (ANOVA) in Table 5 showed that the regression was statistically significant $(\mathrm{P}<0.05)$ at a $95 \%$ confidence level. The model presented a high regression coefficient of 0.9694 .

$$
y(m g / L)=577.732+71.327 x_{1}-54.053 x_{2}-46.802 x_{1}^{2}-106.449 x_{2}^{2}-24.010 x_{1} x_{2}
$$




\begin{tabular}{|c|c|c|c|c|}
\hline \multirow{2}{*}{ Runs } & \multirow{2}{*}{$x_{1}(\mathrm{~g} / \mathrm{L})$ Glycerol } & \multirow{2}{*}{$x_{2}(\mathrm{~g} / \mathrm{L})$ Peptone } & \multicolumn{2}{|c|}{$y(\mathrm{mg} / \mathrm{L})$ Plt production } \\
\cline { 3 - 5 } & $21(+1)$ & $24(+1)$ & $444.8 \pm 22.1^{\mathrm{a}}$ & 417.7 \\
\hline 1 & $21(+1)$ & $16(-1)$ & $593.9 \pm 35.2$ & 573.9 \\
\hline 2 & $15(-1)$ & $24(+1)$ & $311.8 \pm 17.5$ & 323.1 \\
\hline 3 & $15(-1)$ & $16(-1)$ & $364.9 \pm 20.4$ & 383.2 \\
\hline 4 & $22.242(1.414)$ & $20(0)$ & $553.4 \pm 10.9$ & 585.0 \\
\hline 5 & $13.758(-1.414)$ & $20(0)$ & $405.9 \pm 25.0$ & 383.3 \\
\hline 6 & $18(0)$ & $25.696(1.414)$ & $278.9 \pm 14.1$ & 288.4 \\
\hline 7 & $18(0)$ & $14.304(-1.414)$ & $441.8 \pm 19.4$ & 441.3 \\
\hline 8 & $18(0)$ & $20(0)$ & 548.1 & 577.7 \\
\hline $9 \mathrm{~b}$ & $18(0)$ & $20(0)$ & 573.6 & 577.7 \\
\hline 10 & $18(0)$ & $20(0)$ & 602.1 & 577.7 \\
\hline 11 & $18(0)$ & $20(0)$ & 589.6 & 577.7 \\
\hline 12 & $18(0)$ & $20(0)$ & 575.1 & 577.7 \\
\hline 13 & & & & \\
\hline
\end{tabular}

Table 3. Experimental design and responses of the central composite design (CCD). a Samples were taken at $72 \mathrm{~h}$, and the standard deviation was calculated from three independent samples. ${ }^{b}$ Runs 9-13 were replicates at the center point.

\begin{tabular}{|c|c|c|c|c|}
\hline Parameters & Parameter estimate & Standard error & T value & $\operatorname{Pr}>|\mathrm{t}|$ \\
\hline Intercept & 577.732 & 11.746 & 49.184 & $<0.0001$ \\
\hline$\beta_{1}$ & 71.327 & 9.286 & 7.681 & $<0.0001$ \\
\hline$\beta_{2}$ & -54.053 & 9.286 & -5.821 & 0.001 \\
\hline$\beta_{11}$ & -46.802 & 9.958 & -4.700 & 0.002 \\
\hline$\beta_{22}$ & -106.449 & 9.958 & -10.689 & $<0.0001$ \\
\hline$\beta_{12}$ & -24.010 & 13.133 & -1.828 & 0.110 \\
\hline
\end{tabular}

Table 4. Regression results from the data of central composite design (CCD) experiments $x_{1}$ : glycerol concentration; $x_{2}$ : peptone concentration

\begin{tabular}{|c|c|c|c|c|}
\hline Regression & DF & Sum of squares & F value & Pr $>$ F \\
\hline Linear & 2 & 64075 & 46.44 & $<0.0001$ \\
\hline Quadratic & 2 & 86495 & 62.69 & $<0.0001$ \\
\hline Crossproduct & 1 & 2306 & 3.34 & 0.110 \\
\hline Total model & 5 & 152876 & 44.32 & $<0.0001$ \\
\hline
\end{tabular}

Table 5. ANOVA results for Plt production obtained from central composite design (CCD) experiments 
The response surface plot obtained from Eq. (2) is shown in Fig. 4. Based on the canonical analysis produced by the SAS software, it is evident that Plt production reached its maximum at a combination of coded level 0.85 ( $x_{1}$, glycerol) and -0.35 ( $x_{2}$, peptone). The model predicted a maximum response of $617.6 \mathrm{mg} / \mathrm{L}$ Plt at $20.55 \mathrm{~g} / \mathrm{L}$ glycerol and $18.6 \mathrm{~g} / \mathrm{L}$ peptone levels as optimized medium components.

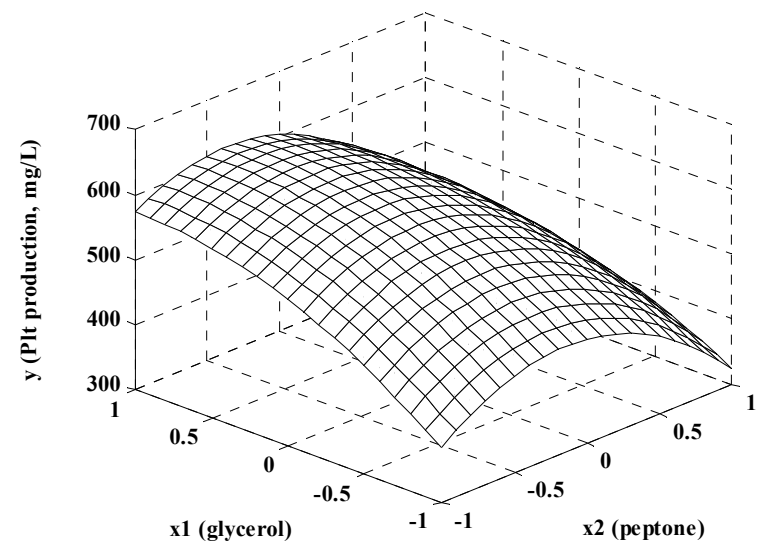

Fig. 4. The response surface curve of the effect of glycerol and peptone on Plt production by P.M18R.

To confirm the above prediction, experiments using both optimized (as predicted) and nonoptimized media (18 g/L glycerol and $20 \mathrm{~g} / \mathrm{L}$ peptone) were performed. The results are shown in Fig. 5. Similar time profiles of cell growth (OD600) were observed for both optimized and non-optimized media. A maximum Plt production titre of $648.3 \pm 20.1 \mathrm{mg} / \mathrm{L}$ for 72 hours of cultivation was obtained for the cells cultured in the optimized medium, which was higher than that in the non-optimized medium.
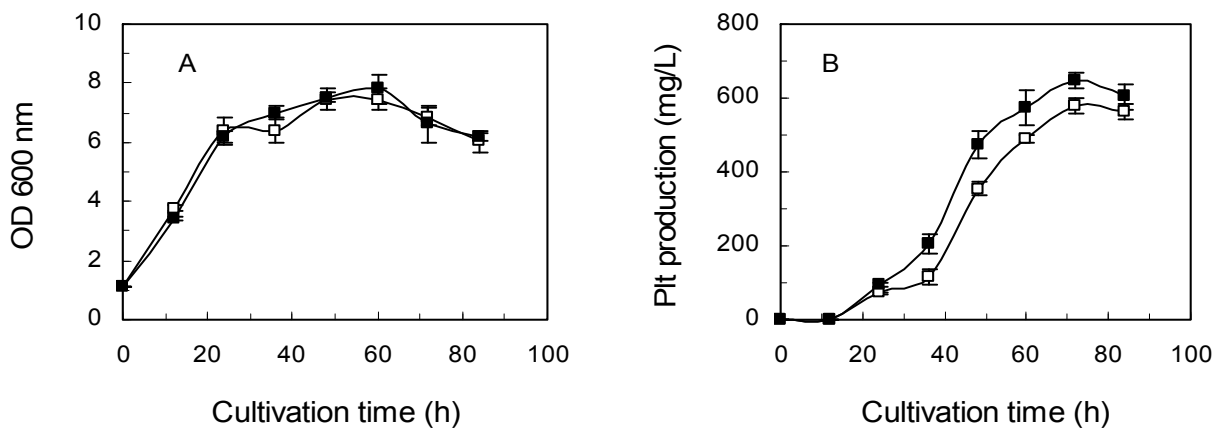

Fig. 5. Time profiles of cell growth (A) and Plt production (B) for the cell culture of $P$. M18R in different media. Symbols: non-optimized medium (open square), optimized medium (dark square). The error bars in the figure indicate the standard deviations from three independent samples. 
The effects of major nutrients such as carbon/nitrogen sources as well as the ratios on Plt production were studied for the cell culture of Pseudomonas $s p$. M18R in order to obtain a suitable fermentation medium. The findings show that the most favorable carbon source for Plt biosynthesis in Pseudomonas sp. M18R was glycerol. The Plt production titre in a glycerol medium $(540.2 \pm 20.0 \mathrm{mg} / \mathrm{L})$ was about $1.29,2.00,2.54,4.51,11.80$, and 14.50 times of that in fructose, ethanol, glucose, sucrose, lactose, and maltose media for 72 hours of cultivation, respectively. The same results were obtained in the cell culture of the biocontrol strain Pseudomonas fluorescens CHA0. The respective Plt production titre in 48 hours was about 220, 50, and $10 \mathrm{ng} / 10^{8} \mathrm{CFU}$ in glycerol, fructose, and glucose media (Duffy \& Defago, 1999). However, ethanol showed the highest Plt production for the cell culture of Pseudomonas fluorescens S272. The Plt production titre was about as twice of that in the ethanol medium $(56 \mathrm{mg} / \mathrm{L})$ as in the glycerol medium $(26 \mathrm{mg} / \mathrm{L})$ for 72 hours. Moreover, no Plt was observed in other carbons such as fructose, glucose, and sucrose, among others (Yuan et al., 1998). These results showed that the effect of carbon source on Plt production seemed to be strain dependent. For the organic nitrogen investigated, the Plt production titer was much higher in peptone than in yeast extract, casein enzymatic hydrolysate, and casein acid hydrolysate for our cell, and only a little Plt was observed in inorganic nitrogen such as ammonium nitrate (data not shown). In the cell culture of Pseudomonas fluorescens S272, similar result for the respective Plt production titer of 124,88 , and $31 \mathrm{mg} / \mathrm{L}$ in peptone, soybean, and ammonium nitrate medium was obtained (Yuan et al., 1998). According to the central composite design and response surface analysis, maximum Plt production $(648.3 \pm 20.1 \mathrm{mg} / \mathrm{L})$ and productivity $(9.01 \pm 0.28 \mathrm{mg} / \mathrm{L}$ per hour) were successfully obtained using $20.55 \mathrm{~g} / \mathrm{L}$ of glycerol and $18.6 \mathrm{~g} / \mathrm{L}$ of peptone by the cell culture of Pseudomonas sp. M18R. The production titer of Plt for the cell culture of M18R obtained in this work increased about 10 times.

\subsubsection{Experiments on mineral sources}

The effects of mineral sources on Plt production in cell culture of M18R were investigated and the results were shown in Table 6. Plt production was influenced by addition of $0.02 \mathrm{~g} / \mathrm{L}$ $\mathrm{ZnSO}_{4}, \mathrm{CuSO}_{4}, \mathrm{FeSO}_{4}$ or $\mathrm{CoCl}_{2}$, whereas $\mathrm{MnCl}_{2}$ or $\mathrm{NaCl}$ have no effects on it.

\begin{tabular}{|c|c|}
\hline Culture medium & Plt Production $(\mathrm{mg} / \mathrm{L})$ \\
\hline Control & $609.5 \pm 21.4$ \\
\hline $\mathrm{ZnSO}_{4}$ & $643.0 \pm 26.9$ \\
\hline $\mathrm{CuSO}_{4}$ & $553.0 \pm 25.1$ \\
\hline $\mathrm{FeSO}_{4}$ & $507.8 \pm 17.8$ \\
\hline $\mathrm{MnCl}_{2}$ & $626.3 \pm 33.2$ \\
\hline $\mathrm{CoCl}_{2}$ & $640.2 \pm 30.9$ \\
\hline $\mathrm{NaCl}$ & $614.7 \pm 28.4$ \\
\hline
\end{tabular}

Table 6. Effects of different mineral sources on Plt production for P.M18R cultivation on 72h.

From Table 6 we could see that $\mathrm{ZnSO}_{4}$ or $\mathrm{CoCl}_{2}$ could enhance Plt production in P.M18R, the same results was obtained in Pseudomonas fluorescens CHA0 (Duffy \& Defago, 1999). Plt production was decreased by the addition of $0.02 \mathrm{~g} / \mathrm{L} \mathrm{FeSO}_{4}$ in P.M18R, but increased by 
the addition of $0.15 \mathrm{~g} / \mathrm{L} \mathrm{FeSO}_{4}$ in Pseudomonas fluorescens CHA0 (Duffy \& Defago, 1999). High $\mathrm{NaCl}$ concentration (15 g/L) could increase the production of Plt in Pseudomonas fluorescens S272 (Nakata et al., 1999), however no effects was observed in our research. These results indicated that not only the mineral sources, but also the mineral concentration have obvious effects on Plt production. The optimal concentration for each mineral in cell culture of M18R is still under research.

\subsubsection{Scale-up fermentation of M18R}

A $10 \mathrm{~L}$ bioreactor was adopted to test the optimized medium conditions obtained in shake flask and the Plt production were shown in Table 7. Plt attained a maximal production of $708.1 \pm 35.7 \mathrm{mg} / \mathrm{L}$ in $78 \mathrm{~h}$, a little higher than that in flasks. The productivity of Plt in flask and bioreactor cultivation were nearly at the same level.

\begin{tabular}{|c|c|c|}
\hline Culture condition & Plt production $(\mathrm{mg} / \mathrm{L})$ & Plt productivity (mg/L per hour) \\
\hline Flask cultivation $(72 \mathrm{~h})$ & $673.8 \pm 25.6$ & $9.36 \pm 0.57$ \\
\hline Bioreactor cultivation $(78 \mathrm{~h})$ & $708.1 \pm 35.7$ & $9.08 \pm 0.78$ \\
\hline
\end{tabular}

Table 7. Scale-up fermentation of $P$. M18R for Plt production.

\subsection{Purification of PIt from the fermentation broth of M18R}

\subsubsection{Extraction of PIt from the fermentation broth}

The solubility of Plt in different solvents was analyzed (see Table 8), and ethyl acetate was selected as the extract solvent.

\begin{tabular}{|c|c|}
\hline Solvent & Plt solubility $(\mathrm{g} / \mathrm{L})$ \\
\hline Methanol & $761.7 \pm 26.1$ \\
\hline Ethanol & $750.8 \pm 34.5$ \\
\hline Acetone & $786.7 \pm 37.4$ \\
\hline Ethyl acetate & $520.7 \pm 12.8$ \\
\hline Chloroform & $90.1 \pm 3.1$ \\
\hline Dichloromethane & $13.82 \pm 0.06$ \\
\hline Carbon tetrachloride & $0.88 \pm 0.03$ \\
\hline Water & $0.75 \pm 0.01$ \\
\hline
\end{tabular}

Table 8. Solubility of Plt in different solvents at $293.2 \mathrm{~K}$.

The extract times and the volume ratio of the organic solvent used were studied, and the results were shown in Table 9. Every $5 \mathrm{~mL}$ fermentation broth was used for each condition and each experiment was carried out in triplicate. Plt content in the extract increased from $538.7 \mathrm{mg} / \mathrm{L}$ to $624.2 \mathrm{mg} / \mathrm{L}$ with the increasing of the volume ratio of ethyl acetate and fermentation broth from 0.5:1 to 2:1 for once extraction. When extracted twice, the volume ratio of organic solvent and culture broth have no influence on Plt extraction and all data for twice extraction were higher than once extraction. 


\begin{tabular}{|c|c|c|}
\hline \multicolumn{2}{|c|}{ Extract methods } & \multirow{2}{*}{ Plt (mg/L) } \\
\hline Extract times & Volume ratio of ethyl acetate and fermentation broth & \\
\hline \multirow{3}{*}{ Once } & $0.5: 1$ & $538.7 \pm 4.8$ \\
\cline { 2 - 3 } & $1: 1$ & $597.6 \pm 33.9$ \\
\cline { 2 - 3 } & $2: 1$ & $624.2 \pm 25.6$ \\
\hline \multirow{3}{*}{ Twice } & $0.5: 1$ & $691.9 \pm 8.8$ \\
\cline { 2 - 3 } & $1: 1$ & $698.0 \pm 60.0$ \\
\cline { 2 - 3 } & $2: 1$ & $687.8 \pm 12.3$ \\
\hline
\end{tabular}

Table 9. Extract methods of Plt from the fermentation broth

From this result, $2 \mathrm{~L}$ fermentation broth was extracted with ethyl acetate twice and $1 \mathrm{~L}$ ester were used for each time. The extraction were combined and evaporated at $40^{\circ} \mathrm{C}$ to dry and $1.204 \mathrm{~g}$ of crude Plt was obtained.

\subsubsection{Silica gel column chromatography}

Samples of Plt extract (1.204 g) was mixed with $2.5 \mathrm{~g}$ silica gel and loading onto a glass silica gel column after grinding. The column was eluted with benzene-acetate acid (20:1, vol) and every $50 \mathrm{~mL}$ of the elution was collected and evaporated at $40^{\circ} \mathrm{C}$ to dry. The residues were dissolved in methanol and analyzed by HPLC, the fractions that contained Plt were combined and about $0.953 \mathrm{~g}$ of crude Plt was obtained. The HPLC chromatogram shown a purity of Plt was about $89 \%$ for this crude sample and further purification need to be done.

\subsubsection{High performance liquid chromatography of PIt}

Elution conditions of crude Plt were investigated on preparative HPLC column and the chromatogram were shown in Fig. 6 . When $70 \%$ methanol was used as the mobile phase, the peaks of Plt and the main impurity were very near and their respective retention time were $7.26 \mathrm{~min}$ and $5.05 \mathrm{~min}$. Decreasing methanol concentration from $70 \%$ to $50 \%$ could increase the retention time between Plt and the main impurity from $2.21 \mathrm{~min}$ to $17.04 \mathrm{~min}$. Therefore, using $50 \%$ methanol as the mobile phase would be beneficial to the separation of massive samples on preparative column.
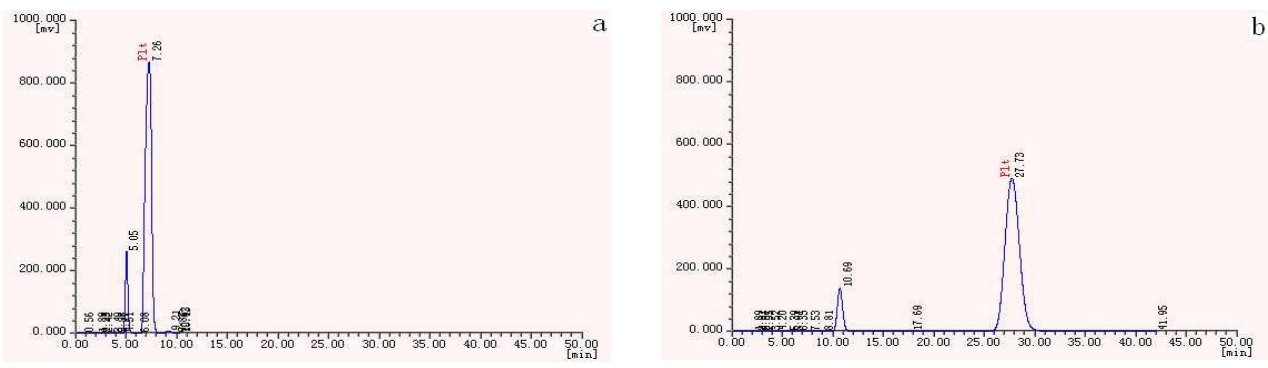

Fig. 6. Optimization of mobile phase on preparative HPLC. Conditions: C-18 column $\left(300 \times 20 \mathrm{~mm}^{2}, 5 \mu \mathrm{m}\right)$; flow-rate: $15 \mathrm{~mL} / \mathrm{min}$; detection wavelength: $308 \mathrm{~nm}$. a: $70 \%$ methanol; b: $50 \%$ methanol 

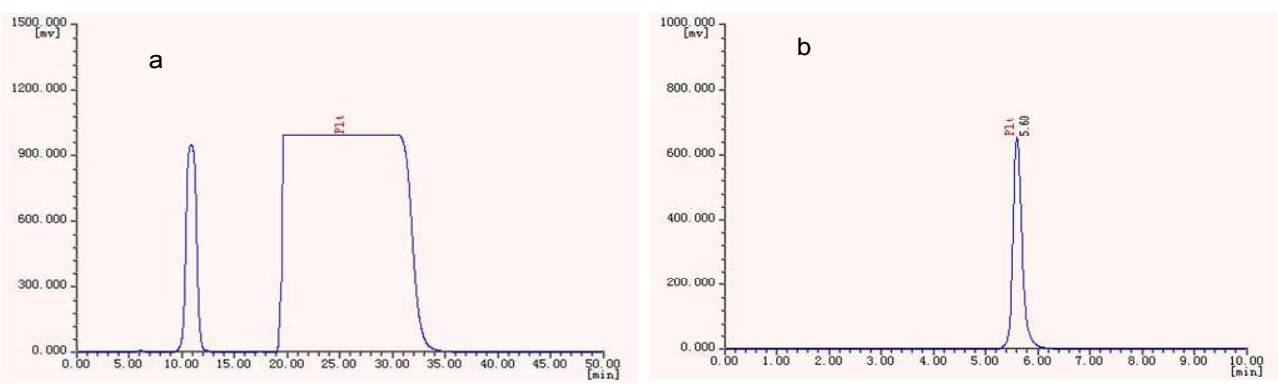

Fig. 7. a: Preparative HPLC chromatogram for Plt purification. Conditions: C-18 column (300 $\mathrm{mm} \times 20 \mathrm{~mm}$ i.d., $5 \mu \mathrm{m}$ ); mobile phase: $50 \%$ methanol; flow-rate: $15 \mathrm{~mL} / \mathrm{min}$; detection wavelength: $308 \mathrm{~nm}$. b: HPLC chromatogram of Plt after purification by preparative HPLC. Conditions: C-18 column ( $250 \mathrm{~mm} \times 4.6 \mathrm{~mm}$ i.d., $5 \mu \mathrm{m})$; mobile phase: $70 \%$ methanol; flowrate: $1 \mathrm{~mL} / \mathrm{min}$; detection wavelength: $308 \mathrm{~nm}$.

Crude Plt $(0.953 \mathrm{~g})$ was dissolved in $50 \%$ methanol to a total volume of $4 \mathrm{~mL}$ and then purified by preparative HPLC. The biggest peak (see Fig. 7a) was collected and evaporated to dry and $0.841 \mathrm{~g}$ yellow crystal was finally obtained. Structure of the crystal was confirmed to be Plt by means of modern spectroscopic techniques, including UV, MS, 13C NMR and $2 \mathrm{H}$ NMR (data not shown). HPLC chromatogram of Plt crystal was shown in Fig. $7 \mathrm{~b}$ and its purity was about $99 \%$.

The results of Plt purification from the culture broth were shown in Table 10. From the table we could see that $0.841 \mathrm{~g}$ Plt was obtained from $2 \mathrm{~L}$ culture broth with a total recovery of about $69.8 \%$.

\begin{tabular}{|c|c|c|c|}
\hline Purification steps & $\begin{array}{c}\text { Plt quantity } \\
(\mathrm{g})\end{array}$ & $\begin{array}{c}\text { Plt Purity } \\
(\%)\end{array}$ & $\begin{array}{c}\text { Recovery } \\
(\%)\end{array}$ \\
\hline Extract with ethyl acetate & 1.204 & 38.8 & 100 \\
\hline Silica gel column chromatography & 0.953 & 89.1 & 79.2 \\
\hline Preparative HPLC & 0.841 & 98.9 & 69.8 \\
\hline
\end{tabular}

Table 10. The results of Plt purification

\subsection{Trace analysis of PIt by CE}

\subsubsection{Effect of applied voltage}

For the trace analysis of Plt by CE, applied voltage (ranging from 5 to $25 \mathrm{kV}$ ) has an obvious influence on migration time (Fig.8 (A)), peak height and peak area (Fig.10 (A)). With the decrease of the running voltage, the migration time of Plt increased and their corresponding peak height and peak area were heightened, which represented high detection sensitivity. Effect of applied voltage on separation of Plt and PCA (IS) was also investigated (Fig.9 (A)). The experiment showed no obvious variation on resolution. Considering the requirement for detection sensitivity, $10 \mathrm{kV}$ was selected as the optimum applied voltage in this experiment. 


\subsubsection{Effect of buffer $\mathrm{pH}$ values and buffer concentration}

The $\mathrm{pH}$ of the electrolyte buffer (ranging from 8.3 to 9.0) plays an important role in both electroosmotic flow (EOF) and electrophoretic mobilities of the analytes, so as to impact the resolution (Fig.9 (B)). The experiment demonstrated that the increase of $\mathrm{pH}$ value led to a decrease in the migration time of PCA (Fig.8 (B)) and a certain increase in peak height but little change in peak area (Fig.10 (B)). However, the migration time of Plt (Fig.8 (B)) was reduced with $\mathrm{pH}$ values between 8.3 and 8.6 , and then rose back when the $\mathrm{pH}$ value reached 8.6. Besides, the resolution of Plt and PCA decreased as the $\mathrm{pH}$ values increased, but Plt and methanol can not be separated with $\mathrm{pH}$ values below 8.4. For a comprehensive thought, the $\mathrm{pH}$ value of the background electrolyte buffer is controlled at 8.6, to get good resolutions of both Plt and PCA, and Plt and methanol.
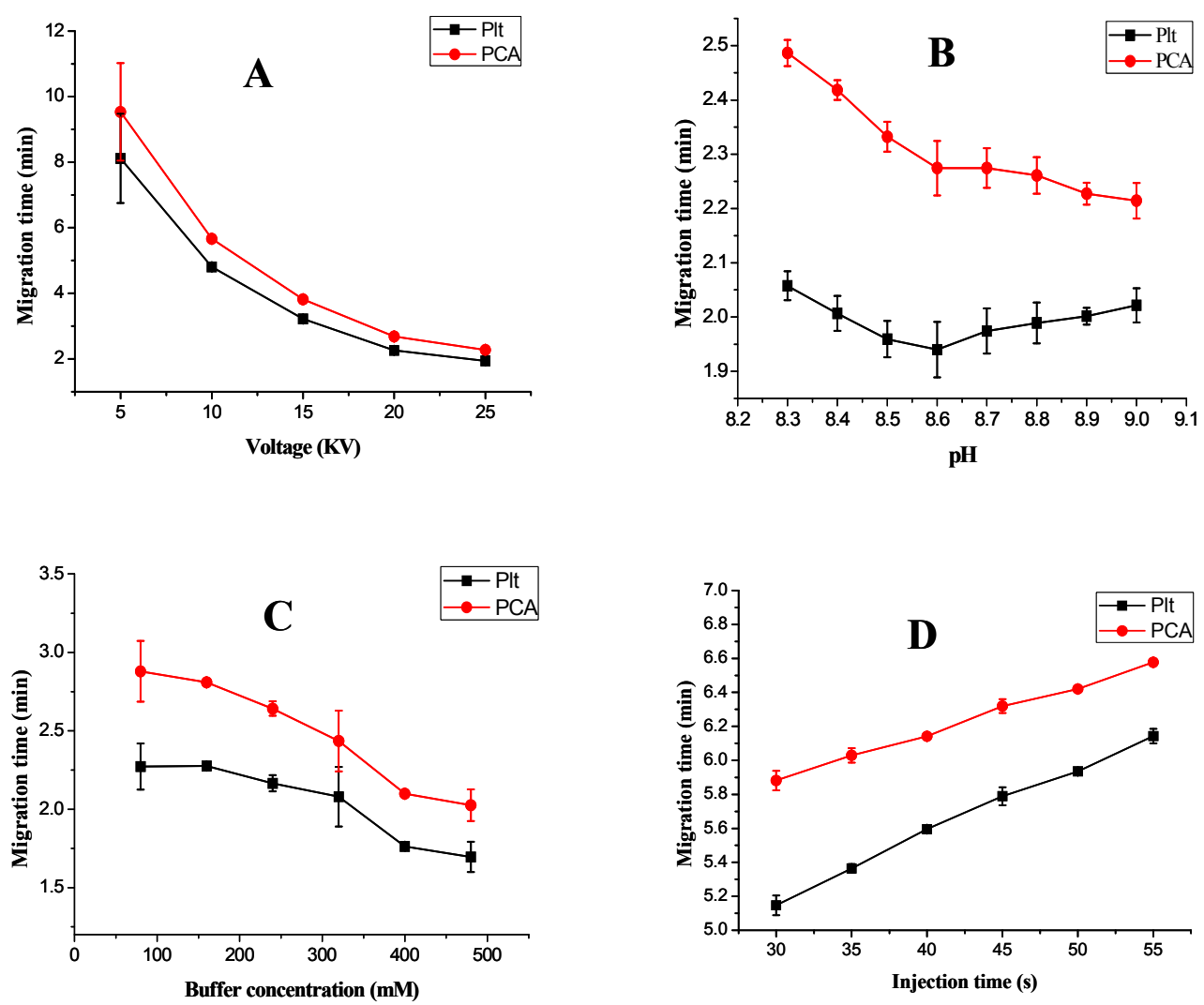

Fig. 8. Effects to the migration time of Plt and PCA in stacking $\mathrm{CE}$ by voltage (A), $\mathrm{pH}$ value (B), buffer concentration (C) and injection time (D) 


\subsubsection{Effect of buffer concentration}

Different concentrations of Gly-NaOH buffer (ranging from 80 to $480 \mathrm{mmol} / \mathrm{L}$ ) have evident influence on electric current, resolution and sensitivity. The results showed that the resolution of Plt and PCA (Fig.9 (C)) increased significantly with the increasing buffer concentrations. When the concentration was $240 \mathrm{mmol} / \mathrm{L}$, the highest peak height and a relatively larger peak area of Plt (Fig.10 (C)) were gained. So, $240 \mathrm{mmol} / \mathrm{L}$ was selected as the optimum background buffer concentration in view of good detection sensitivity and resolution.
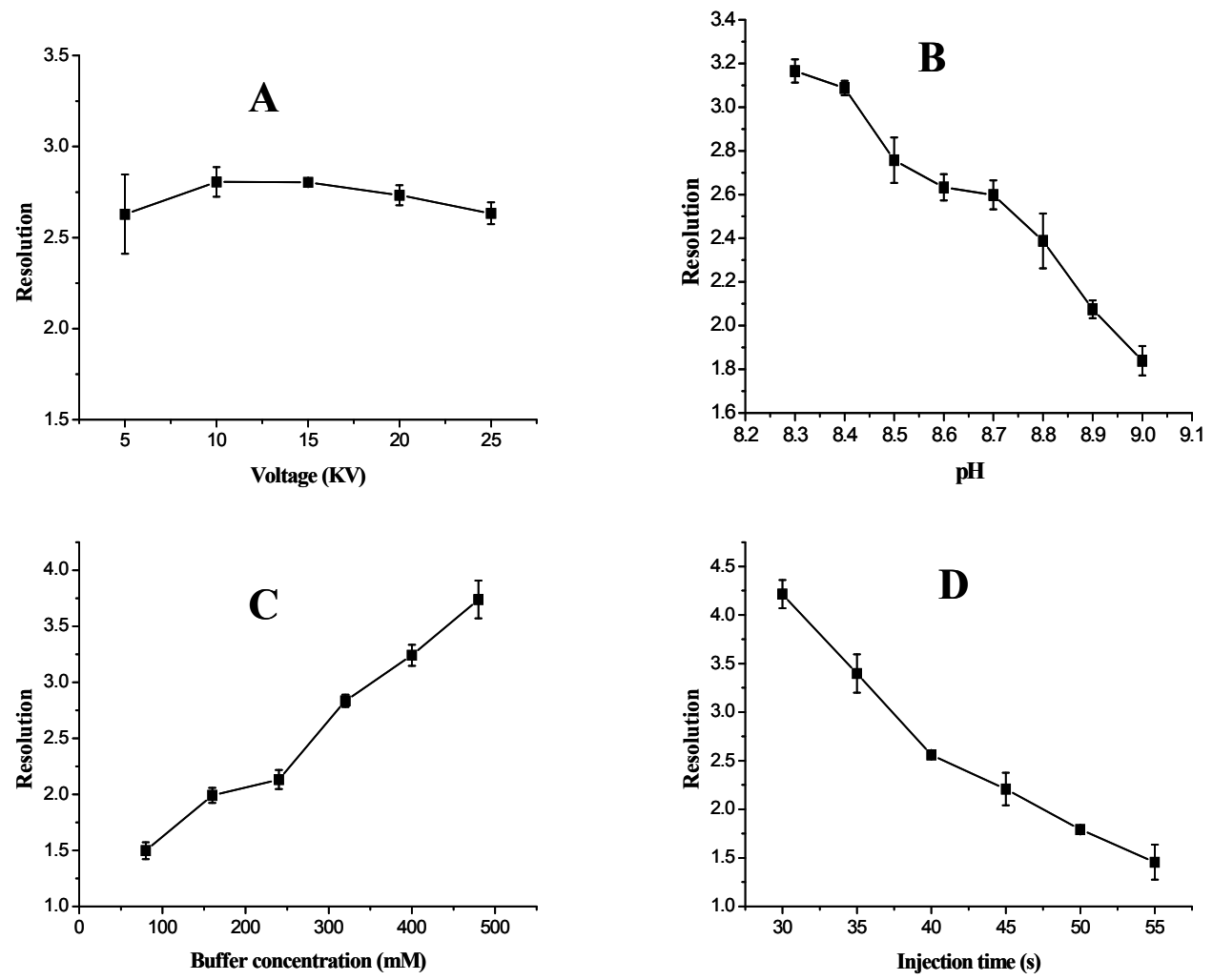

Fig. 9. Effects to the resolution of Plt and PCA in stacking CE by voltage (A), $\mathrm{pH}$ value (B), buffer concentration (C) and injection time (D) 

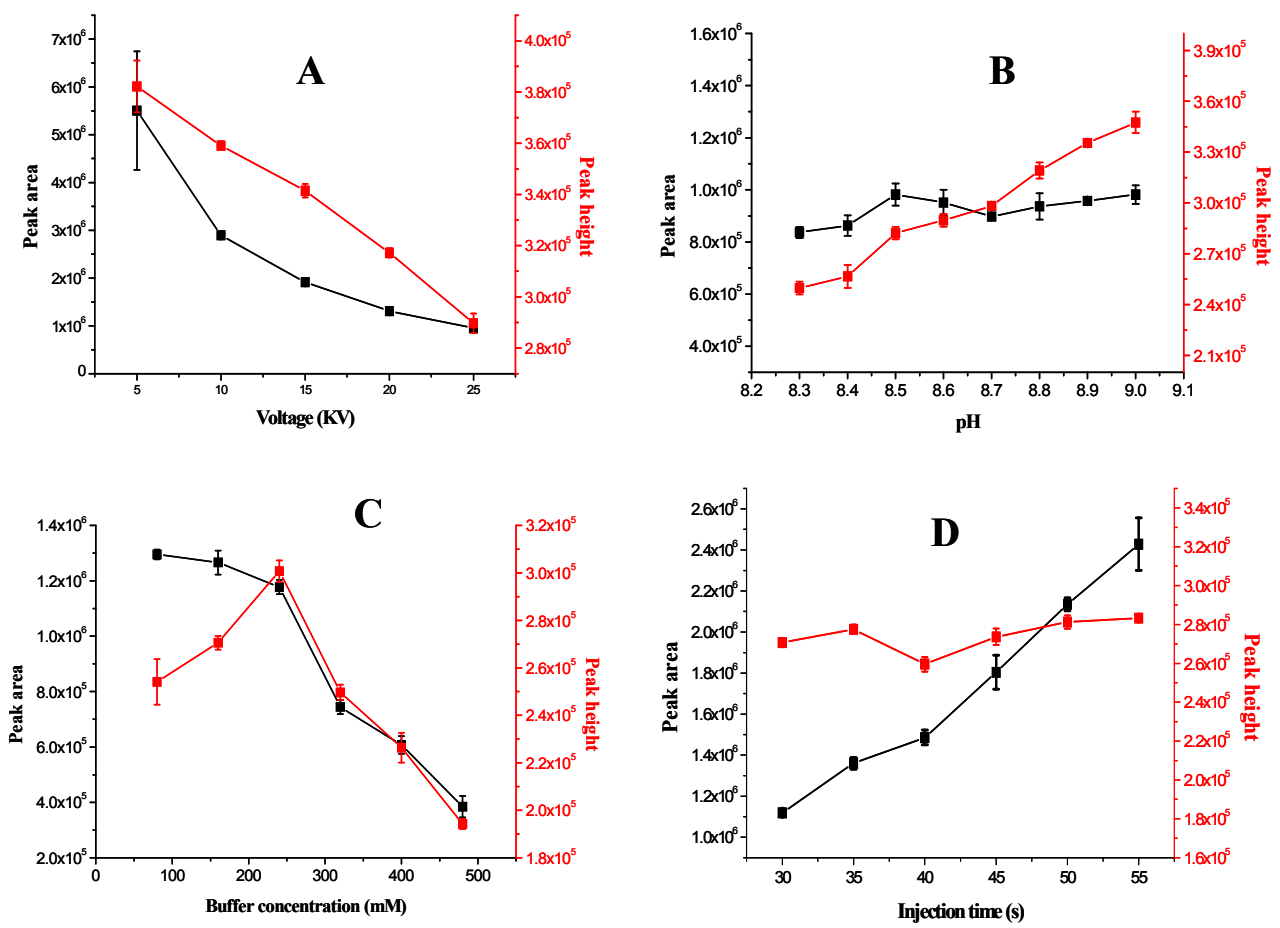

Fig. 10. Effects to the peak area and peak height of Plt in stacking CE by voltage (A), pH value (B), buffer concentration (C) and injection time (D)

\subsubsection{Effect of injection time}

The injection time (ranging from 30 to $55 \mathrm{~s}$ ) impacts the sensitivity and resolution significantly. As the injection time increased, the resolution of Plt and PCA (Fig.9 (D)) got poorer (destroyed with injection time at $55 \mathrm{~s}$ ), a great increase in peak area and little variation in peak height of Plt (Fig.10 (D)) was gained. Considering the requirement for both sensitivity and resolution, a $45 \mathrm{~s}$ injection time was selected.

\subsubsection{Validity of the developed methods}

Finally, we achieved the following optimized CE conditions: $240 \mathrm{mmol} / \mathrm{L}, \mathrm{pH} 8.6 \mathrm{Gly}-$ $\mathrm{NaOH}$ buffer, a fused-silica capillary of total length $53 \mathrm{~cm} \times 75 \mu \mathrm{m}$ ID, $375 \mu \mathrm{m}$ OD, with effective length $44 \mathrm{~cm}, 10 \mathrm{kV}, 13$ mbar $45 \mathrm{~s}$ pressure sample injection, and $25^{\circ} \mathrm{C}$ air-cooling for room temperature control. The method was validated for specificity, linearity and precision. The results showed that the method we developed had a good specificity and linearity for trace Plt analysis (Dong et al., 2011).

The precision of the developed method was evaluated by measuring inter-day and intra-day standard deviations (S.D.) and the relative standard deviations (R.S.D.) of both migration time and peak area ratios between the analyte and the IS. The intra-day values of S.D. and 
R.S.D. were calculated based on six replicate injections of the four different concentrations within a day, while inter-day values were evaluated with six replicate injections of the same standard concentration in 6 days. The two precise results are listed in Table 11, which imply the stable analytic conditions and good repeatability of this method.

\begin{tabular}{|c|c|c|c|c|c|c|c|}
\hline \multirow{5}{*}{} & $\begin{array}{c}\text { Sample } \\
\text { concentration }\end{array}$ & \multicolumn{3}{|c|}{ Migration time } & \multicolumn{3}{c|}{ Peak area ratio } \\
\cline { 2 - 8 } & $(\mu \mathrm{g} / \mathrm{mL})$ & $\begin{array}{c}\text { Mean } \\
(\mathrm{min})\end{array}$ & S.D. & $\begin{array}{c}\text { RSD } \\
(\%)\end{array}$ & $\begin{array}{c}\text { Mean } \\
\left(10^{6}\right)\end{array}$ & $\begin{array}{c}\text { S.D. } \\
(106)\end{array}$ & $\begin{array}{c}\text { RSD } \\
(\%)\end{array}$ \\
\hline \multirow{4}{*}{ Intra-day } & 100 & 6.295 & 0.223 & 3.54 & 4.585 & 0.298 & 3.64 \\
\cline { 2 - 8 } & 75 & 6.468 & 0.194 & 2.99 & 3.696 & 0.096 & 2.61 \\
\cline { 2 - 8 } & 25 & 6.323 & 0.068 & 1.08 & 1.171 & 0.039 & 3.36 \\
\cline { 2 - 8 } & 0.5 & 6.209 & 0.121 & 1.95 & 0.012 & 0.000 & 3.30 \\
\hline \multirow{4}{*}{ Inter-day } & 100 & 6.242 & 0.217 & 3.42 & 4.781 & 0.174 & 3.63 \\
\cline { 2 - 8 } & 75 & 6.309 & 0.297 & 4.58 & 3.411 & 0.125 & 3.65 \\
\cline { 2 - 8 } & 25 & 6.328 & 0.238 & 3.65 & 1.162 & 0.051 & 4.39 \\
\cline { 2 - 8 } & 0.5 & 6.002 & 0.080 & 1.33 & 0.014 & 0.001 & 4.77 \\
\hline
\end{tabular}

Table 11. Intra-day and inter-day standard deviations of Plt determination $(n=6)$

CZE is a simple method for the monitor of Plt in fermentation liquor (Wang et al., 2005). However, it suffers from poor sensitivity due to the small sample amounts injected for detection. A field-amplified sample stacking advanced by Chien (Chien \& Burgi, 1991) and Burgi (Burgi \& Chien, 1991) was applied to overcome the limitation of CE. The analyte is dissolved in a diluted background electrolyte or pure solvent to form a sample solution with lower conductivity compared with CE buffer solution. When the high potential is applied to capillary, the sample zone generates an amplified electric field, which makes the analyte irons move faster until reaching the CE buffer zone. Thus, stacking could be achieved at the boundary between sample and CE zone. The method has been confirmed on sensitivity improvement of CE analysis for environmental samples (Albert et al., 1997; Palmarsdottir et al., 1997; Liu et al., 2008), and received approval in trace determination of pesticides and other environmental pollutants (Nunez et al., 2002; Carabias-Martinez et al., 2003; Lagarrigue et al., 2008).

Herein, we developed a method of $\mathrm{CE}$ which combined field-amplified sample stacking to analyze trace amount of Plt. The limit of detection (LOD) of this method was $0.107 \mu \mathrm{g} / \mathrm{mL}$, by setting the signal-to-noise ratio at 3:1, and the limit of quantification (LOQ) for Plt was $0.36 \mu \mathrm{g} / \mathrm{mL}$ by setting the signal-to-noise ratio at 10:1. The LOD of our method was much lower than that of HPLC $(10 \mu \mathrm{g} / \mathrm{mL})$ (de Souza \& Raaijmakers, 2003) and CEZ $(0.66 \mu \mathrm{g} / \mathrm{mL})$ (Wang et al., 2005). This result suggests that this method can meet with the requirement of pesticide residue analysis.

\subsection{Degradation of PIt}

\subsubsection{Effect of light source}

When a pesticide is used on farmland, it is exposed to sunlight, which includes both UV light and Vis light. Many compounds are light sensitive, such as aldicarb, parathion, mecoprop, linuron, and chlorpyrifos (Burrows \& Canle, 2002; Anfossi et al., 2006). Thus, it is necessary to study the effect of $\mathrm{UV} / \mathrm{Vis}$ irradiation on the degradation rate of Plt. We used a 
fluorescent lamp (390-760 nm), an incandescent lamp (390-760 nm), a high-pressure mercury lamp (250-450 nm), and sunlight $(280-800 \mathrm{~nm})$ to investigate the effects of different irradiation on Plt degradation and the results is shown in Fig. 11. The photodegradation rate followed first-order kinetics. The half-life of Plt under fluorescent lamps (23.2 d) and incandescent lamp ( $23.5 \mathrm{~d})$ showed little difference from that in the dark $(24.9 \mathrm{~d})$, whereas the high-pressure mercury lamp $(3.1 \mathrm{~d})$ and sunlight $(3.5 \mathrm{~d})$ greatly decreased its half-life.

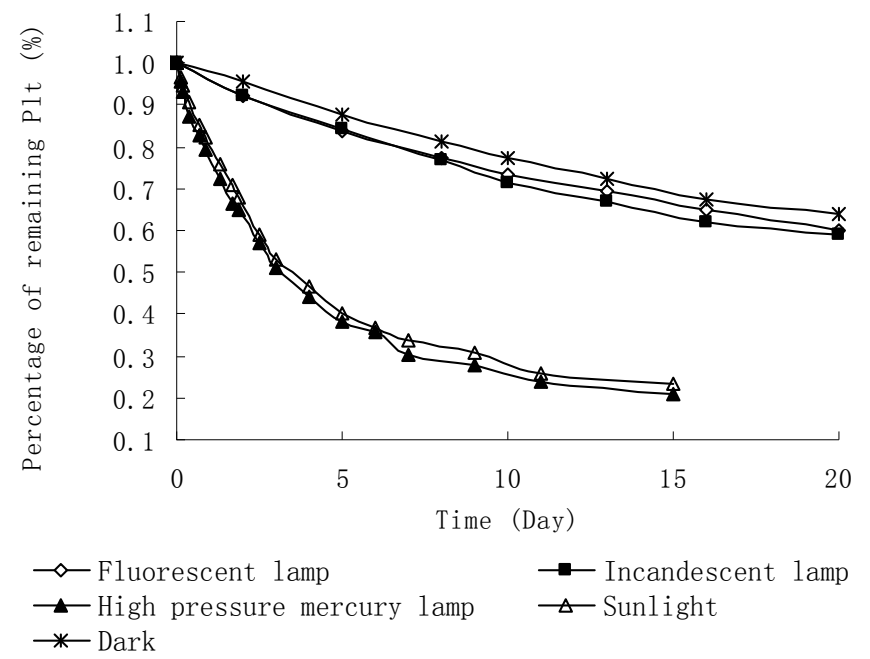

Fig. 11. The degradation of Plt on different light resources (stored at room temperature).

\subsubsection{Effect of $\mathrm{pH}$}

Fig. 12 shows the photodegradation of Plt in buffered solutions at different $\mathrm{pH}$ levels. The degradation rate at different $\mathrm{pH}$ also followed first-order kinetics. The half-life of Plt decreased from $1.77 \mathrm{~d}$ to $0.42 \mathrm{~d}$ with the increasing $\mathrm{pH}$ increased from 5.8 to 7.8. In dark conditions, Plt is relatively stable at the $\mathrm{pH}$ range from $5.8 \sim 7.8$ because the half-life were all

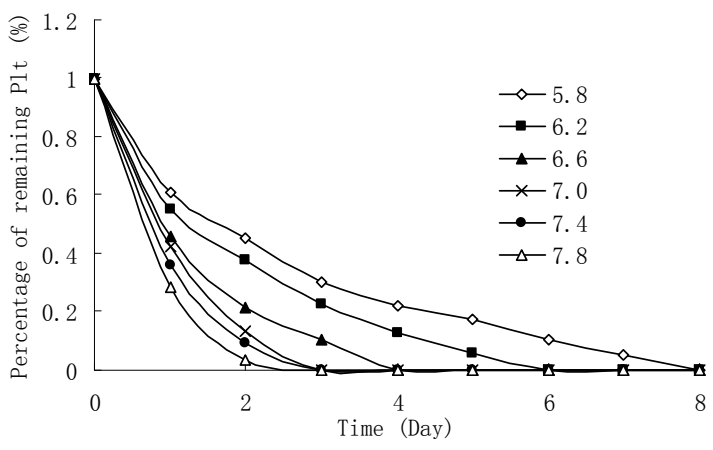

Fig. 12. The photodegradation of Plt at different $\mathrm{pH}$ values (room temperature, under the sunlight). 
above $20 \mathrm{~d}$ (Zhang et al., 2010). This difference might be due to the change of UV-visible spectra of Plt at different solutions (Zhang et al., 2010). The higher efficiency of degradation of Plt under photo irritation at higher $\mathrm{pH}$ values can be due to the higher irradiation absorbance of higher-pH solutions.

\subsubsection{Effect of water sources}

A kinetic model was developed to study the degradation mechanisms and kinetics of Plt, and the results showed that Plt is relatively stable in pure water solutions and at room temperature (Zhang et al., 2010). Here, the stability of Plt in natural water at room temperature was investigated. The degradation of Plt in nature water also followed firstorder reaction kinetics as that in pure water and the results were shown in Table 12. The half-life of Plt in nature water was much shorter $(4.3 \mathrm{~d}$ in lake water and $5.2 \mathrm{~d}$ in rain water) than that in pure water $(24.7 \mathrm{~d})$, suggestted that Plt is unstable in solutions of natural water.

\begin{tabular}{|c|c|c|c|}
\hline Water source & Rate constant $\left(\mathrm{d}^{-1}\right)$ & $\mathrm{R}^{2}$ & Half-life $(\mathrm{d})$ \\
\hline Lake water & 0.1605 & 0.9955 & 4.3 \\
\hline Rain water & 0.1343 & 0.9783 & 5.2 \\
\hline Pure water & 0.0281 & 0.9564 & 24.7 \\
\hline
\end{tabular}

Table 12. Effects of water sources on Plt degradation in the dark at room temperature

The stability of Plt for different treatment of lake water was shown in Table 13, the degradation also followed first-order reaction kinetics. The half-life of Plt in treated lake water (11.4 d in filtered lake water and $16.1 \mathrm{~d}$ in heated lake water) was much longer than that in untreated lake water $(4.3 \mathrm{~d})$, suggestted that there might be Plt degrading bacteria in natural water.

\begin{tabular}{|c|c|c|c|}
\hline Treat method & Rate constant $\left(\mathrm{d}^{-1}\right)$ & $\mathrm{R}^{2}$ & Half-life $(\mathrm{d})$ \\
\hline Untreated & 0.1605 & 0.9675 & 4.3 \\
\hline Filtered & 0.0608 & 0.9483 & 11.4 \\
\hline Heated & 0.0430 & 0.9964 & 16.1 \\
\hline
\end{tabular}

Table 13. Degradation of Plt in treated lake water in the dark at room temperature

\subsubsection{PIt degradation in soil (Dong et al., 2011)}

Plt degradation study was carried out with samples of both near-surface soil $(0 \sim 10 \mathrm{~cm}$ in depth) and rhizosphere soil (10 cm below surface), which were initially spiked with Plt at concentration of $500 \mu \mathrm{g} / \mathrm{kg}$. From the results shown in Fig. 13, it can be found that the degradation of Plt in rhizosphere soil was faster than that near-surface soil, which was possibly due to the higher microbial activity in rhizosphere soil.

Plt degradation in studied soil tended to follow the first-order kinetics. The respective halflife values for Plt residue in near-surface and rhizosphere soil were $42.26 \mathrm{~h}$ and $32.84 \mathrm{~h}$, much shorter than that in pure water. 
On the whole the fast degradation of Plt under natural conditions (under sunlight, in soil, in natural water) demonstrated its excellent biological safety as an antimicrobial pesticide, but also revealed the disadvantage of not up to the requirement for a long control efficiency.

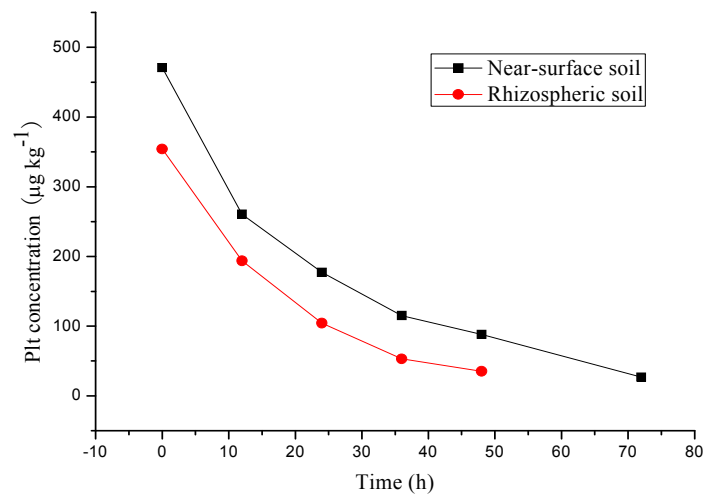

Fig. 13. Degradation curve of PCA in near-surface soil (घ) and rhizosphere soil (•)

\section{Colclusions}

The effects of medium components on the production of Plt through cultivation of the rsmA inactivated mutant strain of Pseudomonas $s p$. M18R were investigated in shake flasks. The carbon sources examined were glycerol, sucrose, glucose, fructose, lactose, maltose, and ethanol, among which the $18 \mathrm{~g} / \mathrm{L}$ glycerol was found to be the most favorable to Plt production. Meanwhile, the nitrogen sources examined were peptone, yeast extract, casein acid hydrolysate, and casein enzymatic hydrolysate, among which the $20 \mathrm{~g} / \mathrm{L}$ peptone was found to be the most favorable to Plt production. To further enhance Plt production, the effects of carbon/nitrogen ratios were studied using central composite design and response surface analysis. The maximum Plt production titre of $648.3 \pm 20.1 \mathrm{mg} / \mathrm{L}$ was achieved in a medium with optimized carbon and nitrogen (i.e., $20.55 \mathrm{~g} / \mathrm{L}$ glycerol and $18.6 \mathrm{~g} / \mathrm{L}$ peptone). The effects of inorganic components on Plt production were also studied. The optimized medium was conducted in bioreactor cultivation, and a maximal production of $708.1 \pm 35.7$ $\mathrm{mg} / \mathrm{L}$ and productivity of $9.08 \pm 0.78 \mathrm{mg} /(\mathrm{L} \cdot \mathrm{h})$ was attained after $78 \mathrm{~h}$ cultivation.

A simple and rapid method for Plt separation and purification from the fermentation broth of Pseudomonas sp. M18R was developed in this paper. Yellow Plt crystal with a purity of about $99 \%$ was obtained through ethyl acetate extraction, silica gel column chromatography and preparative HPLC with a total recovery of about $69.8 \%$.

A sensitive analytical method based on CE with field-amplified sample stacking, Soxhlet's extraction and ultrasonic extraction for studying the trace amounts of Plt in soil samples was also developed. The results showed that this method was of high sensitivity, good linearity and good repeatability, and the whole processing procedures were proved with high recovery and convenience of analysis. This method can also be modified and developed to be applied in the determination of Plt in foods and drinking water.

The degradation of Plt under different conditions, such as water sources, $\mathrm{pH}$ value of solutions, UV intensity, soil et al., were investigated. Degradation of Plt followed first-order reaction kinetics, and it had a high degradation rate in soil, natural water and UV light. Plt 
can decompose quickly in natural conditions suggested that it has good environmental compatibility. However, short residual time brings short reacting time. Thus, the method to improve its stability needs to conduct before its commercial use. The slow-release formulation of Plt in order to prolong its antifungal effects was achieved in our lab (Chen et al., 2010).

Overall, the findings of the study will be beneficial for the further development of the Pseudomonas spp. cultivation process in the large-scale production and the commercial use of Plt.

\section{Acknowledgment}

The financial support of the 973 Programs of China (No. 2009CB118906), the National Natural Science Foundation of China (NSFC project. 20706037), the 863 Programs of China (No. 2006AA10A209) and the Shanghai Leading Academic Discipline Project (Project Number: B203) are gratefully acknowledged.

\section{References}

Albert, M.; Debusschere, L.; Demesmay, C. \& Rocca, J. (1997). Large-volume stacking for quantitative analysis of anions in capillary electrophoresis II. Large-volume stacking without polarity switching. Journal of Chromatography A, 757(1-2), 291-296

Anfossi, L.; Sales, P. \& Vanni, A. (2006). Degradation of anilinopyrimidine fungicides photoinduced by iron (III): cpolycarboxylate complexes. Pest Management Science, 62(9), 872-879

Babalola, O.O. (2010). Beneficial bacteria of agricultural importance. Biotechnology letters, 32(11), 1559-1570

Brodhagen, M.; Henkels, M.D. \& Loper, J.E. (2004). Positive autoregulation and signaling properties of pyoluteorin, an antibiotic produced by the biological control organism Pseudomonas fluorescens Pf-5. Applied and Environmental Microbiology, 70(3), 17581766

Burgi, D.S. \& Chien, R.L. (1991). Optimization in sample stacking for high-performance capillary electrophoresis. Analytical Chemistry, 63(18), 2042-2047

Burrows, H. \& Canle, L. (2002). Reaction pathways and mechanisms of photodegradation of pesticides. Journal of Photochemistry and Photobiology B: Biology, 67(2), 71-108

Carabias-Martinez, R.; Rodriguez-Gonzalo, E.; Revilla-Ruiz, P. \& Dominguez-Alvarez, J. (2003). Solid-phase extraction and sample stacking-micellar electrokinetic capillary chromatography for the determination of multiresidues of herbicides and metabolites. Journal of Chromatography A, 990(1-2), 291-302

Carmi, R.; Carmeli, S.; Levy, E. \& Gough, F.J. (1994). (+)-(S)-Dihydroaeruginoic acid, an inhibitor of Septoria tritici and other phytopathogenic fungi and bacteria, produced by Pseudomonas fluorescens. Journal of natural products, 57(9), 1200-1205

Casas Lopez, J.; Sánchez Pérez, J.; Fernandez Sevilla, J.; Acién Fernández, F.; Molina Grima, E. \& Chisti, Y. (2003). Production of lovastatin by Aspergillus terreus: effects of the C: $\mathrm{N}$ ratio and the principal nutrients on growth and metabolite production. Enzyme and Microbial Technology, 33(2-3), 270-277 
Chang, Y.N.; Huang, J.C.; Lee, C.C.; Shih, I.L. \& Tzeng, Y.M. (2002). Use of response surface methodology to optimize culture medium for production of lovastatin by Monascus ruber. Enzyme and Microbial Technology, 30(7), 889-894

Chen, J.; Wang, W.; Xu, Y. \& Zhang, X. (2010). Slow-release formulation of a new biological pesticide, pyoluteorin, with mesoporous silica. Journal of Agricultural and Food Chemistry, 845-849

Chien, R.L. \& Burgi, D.S. (1991). Field amplified sample injection in high-performance capillary electrophoresis. Journal of Chromatography A, 559(1-2), 141-152

Corbell, N. \& Loper, J. (1995). A global regulator of secondary metabolite production in Pseudomonas fluorescens Pf-5. Journal of Bacteriology, 177(21), 6230-6236

de Souza, J.T. \& Raaijmakers, J.M. (2003). Polymorphisms within the prnD and pltC genes from pyrrolnitrin and pyoluteorin-producing Pseudomonas and Burkholderia spp. FEMS microbiology ecology, 43(1), 21-34

Dong, H.; Gao, B.; Wang, W.; Fan, L.; Xu, Y.; Zhang, X. \& Cao, C. (2011). Experimental study on the determination and degradation of pyoluteorin in soil via CE with Soxhlet's extraction and field-amplified sample stacking. Chromatographia, 73, 609-612

Duffy, B.K. \& Defago, G. (1999). Environmental factors modulating antibiotic and siderophore biosynthesis by Pseudomonas fluorescens biocontrol strains. Applied and Environmental Microbiology, 65(6), 2429-2438

Fang, Q.H. \& Zhong, J.J. (2002). Submerged fermentation of higher fungus Ganoderma lucidum for production of valuable bioactive metabolites--ganoderic acid and polysaccharide. Biochemical Engineering Journal, 10(1), 61-65

Howell, C. \& Stipanovic, R. (1980). Suspension of Pythium ultimum-induced damping-off of cotton seedlings by Pseudomonas fluorescens and its antibiotic, pyoluteorin. Phytopathology, 70(8), 712-715

$\mathrm{Hu}$, H.B.; Xu, Y.Q.; Chen, F.; Zhang, X.H. \& HUR, B.K.I. (2005). Isolation and characterization of a new fluorescent Pseudomonas strain that produces both phenazine 1-carboxylic acid and pyoluteorin. Journal of microbiology and biotechnology, 15(1), 86-90

Huang, X.; Zhu, D.; Ge, Y.; Hu, H.; Zhang, X. \& Xu, Y. (2004). Identification and characterization of pltZ, a gene involved in the repression of pyoluteorin biosynthesis in Pseudomonas sp. M18. FEMS Microbiology Letters, 232(2), 197-202

Kim, H.; Roh, H.; Lee, H.J.; Chung, S.Y.; Choi, S.O.; Lee, K.R. \& Han, S.B. (2003). Determination of phloroglucinol in human plasma by high-performance liquid chromatography-mass spectrometry. Journal of Chromatography B, 792(2), 307-312

La Fuente, L.D.; Thomashow, L.; Weller, D.; Bajsa, N.; Quagliotto, L.; Chernin, L. \& Arias, A. (2004). Pseudomonas fluorescens UP61 isolated from birdsfoot trefoil rhizosphere produces multiple antibiotics and exerts a broad spectrum of biocontrol activity. European Journal of Plant Pathology, 110(7), 671-681

Lagarrigue, M.; Boss“'|e, A.; B“|'gos, A.; Delaunay, N.; Varenne, A.; Gareil, P. \& Bellier, B. (2008). Field-amplified sample stacking for the detection of chemical warfare agent degradation products in low-conductivity matrices by capillary electrophoresismass spectrometry. Journal of Chromatography A, 1178(1-2), 239-247

Laville, J.; Voisard, C.; Keel, C.; Maurhofer, M.; Defago, G. \& Haas, D. (1992). Global control in Pseudomonas fluorescens mediating antibiotic synthesis and suppression of black 
root rot of tobacco. Proceedings of the National Academy of Sciences of the United States of America, 89(5), 1562-1566

Li, Y.Q.; Jiang, H.X.; Xu, Y.Q. \& Zhang, X.H. (2008). Optimization of nutrient components for enhanced phenazine-1-carboxylic acid production by gacA-inactivated Pseudomonas sp. M18G using response surface method. Applied microbiology and biotechnology, 77(6), 1207-1217

Liu, H.M.; Zhang, X.H.; Huang, X.Q.; Cao, C.X. \& Xu, Y.Q. (2008). Rapid quantitative analysis of phenazine-1-carboxylic acid and 2-hydroxyphenazine from fermentation culture of Pseudomonas chlororaphis GP72 by capillary zone electrophoresis. Talanta, 76(2), 276-281

Matano, I.; Tsunekawa, M.; Shimizu, S.; Tanaka, I.; Mitsukura, K. \& Maruyama, K. (2010). The chloride ion is an environmental factor affecting the biosynthesis of pyoluteorin and 2, 4-diacetylphloroglucinol in Pseudomonas sp. YGJ3. Bioscience, biotechnology, and biochemistry, 74(2), 427-429

Maurhofer, M.; Keel, C.; Haas, D. \& Defago, G. (1994). Pyoluteorin production by Pseudomonas fluorescens strain CHA0 is involved in the suppression of Pythium damping-off of cress but not of cucumber. European Journal of Plant Pathology, $100(3), 221-232$

Maurhofer, M.; Keel, C.; Schnider, U.; Voisard, C.; Haas, D. \& Defago, G. (1992). Influence of enhanced antibiotic production in Pseudomonas fluorescens strain CHA0 on its disease suppressive capacity. Phytopathology, 82(2), 190-195

Nakata, K.; Yoshimoto, A. \& Yamada, Y. (1999). Promotion of antibiotic production by high ethanol, high $\mathrm{NaCl}$ concentration, or heat shock in Pseudomonas fluorescens S272. Bioscience, biotechnology, and biochemistry, 63(2), 293-297

Nowak-Thompson, B.; Chaney, N.; Wing, J.S.; Gould, S.J. \& Loper, J.E. (1999). Characterization of the pyoluteorin biosynthetic gene cluster of Pseudomonas fluorescens Pf-5. Journal of Bacteriology, 181(7), 2166-2174

Nunez, O.; Moyano, E. \& Galceran, M. (2002). Solid-phase extraction and sample stackingcapillary electrophoresis for the determination of quaternary ammonium herbicides in drinking water. Journal of Chromatography A, 946(1-2), 275-282

Palmarsdottir, S.; Mathiasson, L.; J nsson, J. \& Edholm, L.E. (1997). Determination of a basic drug, bambuterol, in human plasma by capillary electrophoresis using double stacking for large volume injection and supported liquid membranes for sample pretreatment. Journal of Chromatography B: Biomedical Sciences and Applications, 688(1), 127-134

Park, J.; Kim, S.; Hwang, H. \& Yun, J. (2001). Optimization of submerged culture conditions for the mycelial growth and exo-biopolymer production by Cordyceps militaris. Letters in Applied Microbiology, 33(1), 76-81

Saikia, R.; Varghese, S.; Singh, B.P. \& Arora, D.K. (2009). Influence of mineral amendment on disease suppressive activity of Pseudomonas fluorescens to Fusarium wilt of chickpea. Microbiological Research, 164(4), 365-373

Sarniguet, A.; Kraus, J.; Henkels, M.D.; Muehlchen, A.M. \& Loper, J.E. (1995). The sigma factor sigma $\mathrm{s}$ affects antibiotic production and biological control activity of Pseudomonas fluorescens Pf-5. Proceedings of the National Academy of Sciences of the United States of America, 92(26), 12255-12259 
Schnider, U.; Keel, C.; Blumer, C.; Troxler, J.; Defago, G. \& Haas, D. (1995). Amplification of the housekeeping sigma factor in Pseudomonas fluorescens CHA0 enhances antibiotic production and improves biocontrol abilities. Journal of Bacteriology, 177(18), 53875392

Tekeda, R. (1958). Pseudomonas pigments: I .Pyoluteorin, a new chlorine-containing pigment produced by Pseudomonas aeruginosa. Hakko Kgaku Zasshi, 36, 281-290

Wang, Q.L.; Zhang, X.H.; Fan, L.Y.; Zhang, W.; Xu, Y.Q.; Hu, H.B. \& Cao, C.X. (2005). Quantitative analysis of pyoluteorin in anti-fungal fermentation liquor of Pseudomonas species by capillary zone electrophoresis with UV-vis detector. Journal of Chromatography $B, 826(1-2), 252-256$

Wang, W.; Lu, X.; Qin, X.J.; Zhang, X.H. \& Xu, Y.Q. (2008). Solubility of pyoluteorin in water, dichloromethane, chloroform, and carbon tetrachloride from (278.2 to 333.2) K. Journal of Chemical \& Engineering Data, 53(9), 2241-2243

Whistler, C.A.; Corbell, N.A.; Sarniguet, A.; Ream, W. \& Loper, J.E. (1998). The twocomponent regulators GacS and GacA influence accumulation of the stationaryphase sigma factor sigma $S$ and the stress response in Pseudomonas fluorescens Pf-5. Journal of Bacteriology, 180(24), 6635-6641

Whistler, C.A.; Stockwell, V.O. \& Loper, J.E. (2000). Lon protease influences antibiotic production and UV tolerance of Pseudomonas fluorescens Pf-5. Applied and Environmental Microbiology, 66(7), 2718-2725

Yuan, Z.; Cang, S.; Matsufuji, M.; Nakata, K.; Nagamatsu, Y. \& Yoshimoto, A. (1998). High production of pyoluteorin and 2, 4-diacetylphloroglucinol by Pseudomonas fluorescens S272 grown on ethanol as a sole carbon source. Journal of Fermentation and Bioengineering, 86(6), 559-563

Zhang, J.; Wang, W.; Lu, X.; Xu, Y. \& Zhang, X. (2010). The stability and degradation of a new biological pesticide, pyoluteorin. Pest Management Science, 66(3), 248-252

Zhang, X.; Wang, S.; Geng, H.; Ge, Y.; Huang, X.; Hu, H. \& Xu, Y. (2005). Differential regulation of $r s m A$ gene on biosynthesis of pyoluteorin and phenazine-1-carboxylic acid in Pseudomonas sp. M18. World Journal of Microbiology and Biotechnology, 21(6), 883-889 


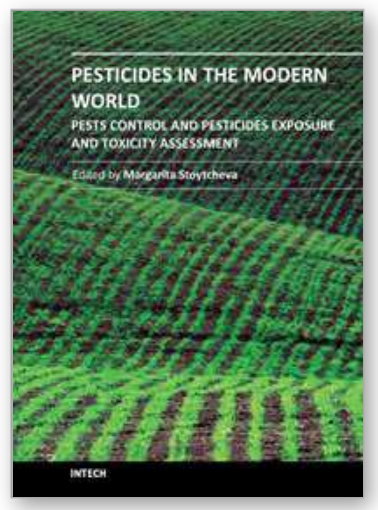

\section{Pesticides in the Modern World - Pests Control and Pesticides Exposure and Toxicity Assessment}

Edited by Dr. Margarita Stoytcheva

ISBN 978-953-307-457-3

Hard cover, 614 pages

Publisher InTech

Published online 30, September, 2011

Published in print edition September, 2011

The present book is a collection of selected original research articles and reviews providing adequate and upto-date information related to pesticides control, assessment, and toxicity. The first section covers a large spectrum of issues associated with the ecological, molecular, and biotechnological approaches to the understanding of the biological control, the mechanism of the biocontrol agents action, and the related effects. Second section provides recent information on biomarkers currently used to evaluate pesticide exposure, effects, and genetic susceptibility of a number of organisms. Some antioxidant enzymes and vitamins as biochemical markers for pesticide toxicity are examined. The inhibition of the cholinesterases as a specific biomarker for organophosphate and carbamate pesticides is commented, too. The third book section addresses to a variety of pesticides toxic effects and related issues including: the molecular mechanisms involved in pesticides-induced toxicity, fish histopathological, physiological, and DNA changes provoked by pesticides exposure, anticoagulant rodenticides mode of action, the potential of the cholinesterase inhibiting organophosphorus and carbamate pesticides, the effects of pesticides on bumblebee, spiders and scorpions, the metabolic fate of the pesticide-derived aromatic amines, etc.

\section{How to reference}

In order to correctly reference this scholarly work, feel free to copy and paste the following:

Wei Wang, Hui Dong, Jingfang Zhang, Yuquan Xu and Xuehong Zhang (2011). The Production, Separation and Stability of Pyoluteorin: A Biological Pesticide, Pesticides in the Modern World - Pests Control and Pesticides Exposure and Toxicity Assessment, Dr. Margarita Stoytcheva (Ed.), ISBN: 978-953-307-457-3, InTech, Available from: http://www.intechopen.com/books/pesticides-in-the-modern-world-pests-control-andpesticides-exposure-and-toxicity-assessment/the-production-separation-and-stability-of-pyoluteorin-abiological-pesticide

\section{INTECH}

open science | open minds

\section{InTech Europe}

University Campus STeP Ri

Slavka Krautzeka 83/A

51000 Rijeka, Croatia

Phone: +385 (51) 770447

Fax: +385 (51) 686166

\section{InTech China}

Unit 405, Office Block, Hotel Equatorial Shanghai

No.65, Yan An Road (West), Shanghai, 200040, China 中国上海市延安西路65号上海国际贵都大饭店办公楼 405 单元

Phone: +86-21-62489820

Fax: +86-21-62489821 
www.intechopen.com 
(C) 2011 The Author(s). Licensee IntechOpen. This chapter is distributed under the terms of the Creative Commons Attribution-NonCommercialShareAlike-3.0 License, which permits use, distribution and reproduction for non-commercial purposes, provided the original is properly cited and derivative works building on this content are distributed under the same license. 